\title{
Enhancing Students' Speaking Skill by Using Youtube Video
}

\author{
Novie Ariyanto, Dewi Rochsantiningsih, Handoko Pudjobroto \\ English Education Department \\ Teacher Training and Education Faculty \\ Sebelas Maret University of Surakarta
}

Email: novieariyanto002@gmail.com

\begin{abstract}
The objective of this article is to report a study on how YouTube video is implemented so it can improve students' speaking proficiency. The study was collaboration classroom action research. The subject of the research was seventh grade students of one state junior high school in Surakarta in the academic year 2012/2013. The data were collected through interview, questionnaire, pre-test, photograph, and post-test. The findings of the research show that when YouTube video was used effectively, it enhanced students' speaking skill, and classroom climate. In conclusion, YouTube video can be applied as an alternative media in language-teaching process include for teaching speaking.
\end{abstract}

Keywords : YouTube video, speaking skill

\section{INTRODUCTION}

Language is an irreplaceable means of communication in human life, since it is used to communicate. English language have been positioned as the primary language to share knowledge and information across nation in the world. Based on this fact, an ability to speak in English is a must to be mastered. Brown and Yule (1983) state that learning to talk in the foreign language is often considered being one of the most difficult aspects of language learning for the teacher to help the students with. The teachers, therefore, are challenged to develop various teaching techniques to encourage their student in learning English. The variety of teaching techniques will also help learners to get higher motivation to learn English. William and Burden (1997:

111) say that motivation is the most powerful influences on learning.

According to Ur (1996:20), there are some problems faced by the learners in speaking activities. The problems include inhibition, the lack of theme to be spoken, the low of participation, and the use of mother tongue. Based on the observation, interview, and pre-test conducted to the seventh grade students, it shows that students' speaking proficiency and motivation is still low. This is indicated from the students' speaking skill and the classroom situation. From the students' speaking skill, indicators of the problem are: 1) Students have difficulties in using correct grammar to express certain meaning. 2) Students find difficulties in using conjunction. They often talk sentence per sentence without linking the sentences by using conjunction. 3) Students find difficulties in using variety of word. They often repeat the same word or expression to deliver the meaning. 4) Students are not able to pronounce the words correctly. 5) Students cannot speak fluently. When speaking English, students often take a long 
time to think of the appropriate words and sentence structures, this make their speech not natural.

Classroom situation which are not favorable is indicated as follows: 1) Students are passively involved in speaking class. They tend to silent almost all the time. 2) Students are doing non-academic activities during the lesson. Instead of paying attention to their teacher, they usually doing non-academic things like playing with their stationary, chatting with other students, drawing picture, bothering other students. 3) Students can't finish the task given in speaking class. 4) During the speaking class, the students only talk to another, when they are asked to do exercise in groups, students tend to chat with their mother tongue about something which is not related with the lesson because they are not interested with the lesson. 5) Students have lack of confidence in speaking English, it shown by their rejection when asked to speak in front of class.

Since English is not a primary language in Indonesia, students are getting nervous when they try to speak their English. The same situation happens in the school being investigated. Students chance to practice is also considered limited, since teacher tends to focus on reading and writing skill. The students' low motivation in learning English makes this condition even worse. There is a possibility that the students' ability in speaking English will remains low if this way of learning continues. Therefore, the teacher must find the way and means to alleviate this situation by using dynamic teaching tool. It is teacher's duty to improve students' motivation through meaningful teaching. So, it is needed to find an appropriate media to teach speaking.
Video can be used as an aid to teach the four skills namely reading, listening, speaking and writing. Cooper (1991: 11) states that video is a supercharged medium of communication and a powerful vehicle of information. It is packed with messages, images, and ambiguity, and so represents a rich terrain to be worked and reworked in the language learning classroom. In addition, Smaldino, et al. (2005: 283) defines video as electronic storage of moving images (videotape, DVD, etc.). Furthermore, Canning-Wilson (2000: 1) states that video is at best defined as the selection and sequence of messages in an audio-visual context. Students feel their interest quicken when language is experienced in a lively way through video. It also brings how people behave in culture whose language they are learning into the classroom. It enables students to have authentic experience in controlled environment. It is also contextualizing language naturally by showing real life into the classroom.

In this research, teaching speaking using YouTube video is introduced. YouTube Video as audio visual aids is beneficial for the teacher and students in English Language Teaching. According to Hopkins (2006: 1) YouTube is a video sharing website on which users can upload, share, and view videos. It uses Adobe Flash Video technology to display a wide variety of user-generated video content, including movie clips, TV clips, and music videos, as well as amateur contents such as video blogging and short original videos. In line with Hopkins, Suparno (2010: 26) defined that YouTube video is one of the audio visual media existing in internet which everyone can access every time.

YouTube video provides a real context of language use; thus, students can practice their speaking in a more 
communicative way that is in a real-life communication. This idea is supported by Smaldino, et al. (2005: 283) who says:

"What is common to most clips is that they are amateur videos which document occurrence from the lives of noncelebrities. As such, the clips provide a huge multimedia library of real language use by real people, a potentially rich resource for language learning or corpus collections."

In brief, teacher can actually make us of a certain video through several attractive activities to engage students' participation in the classroom. Of course, this solely depends on how creative and innovative the teacher develops learning activities.

According to Brophy, J.E. (1988) good classroom management implies not only that the teacher has elicited the cooperation of the students in minimizing misconduct and can intervene effectively when misconduct occurs, but also that worthwhile academic activities are occurring more or less continuously and that the classroom management system as a whole.

Based on the phenomenon above, it is necessary to conduct a classroom action research. This research is originated with Kurt Lewin, an American psychologist, who introduced it in educational research in the mid 1940s. Although the research is classified as either quantitative or qualitative research, the method applied in this research is qualitative methods. It allows us to describe what is happening and to understand the effects of some educational intervention.

The goals of this research were to find out whether YouTube video can improve students' speaking proficiency and to describe how the classroom climate is when YouTube video is implemented.

\section{RESEARCH METHOD}

The method used in this study is a classroom action research in collaboration with the English teacher of the school. Wallace (1998: 4) defines action research as a way of reflecting our teaching. While Mills (2000: 6) defines action research as any systematic inquiry conducted by teacher researchers, principals, school counselors, or other stakeholders in the teaching learning environment, to gather information about the ways that their particular schools operate how they teach, and how well their students learn. This information is gathered with the goals of gaining insight, developing reflective practice, effecting positive changes in the school environment (and on educational practices in general), and improving student outcomes and the lives of those involved. (Mills, 2000: 6).

Burns (1999: 30) states that "action research is the application of fact finding to practical problem solving in social situation with a view to improving the quality of action within it, involving the collaboration and co-operation of researchers, practitioners and laymen". Bodgan and Biklen (in Burns, 1999: 30) define action research as the systematic collection of information that is designed to bring about social change. Kemmis and Mc Taggart (1988) in Nunan (1992: 17) state that there are three characteristics of the action research. Firstly, the action research is carried out by practitioners rather than outside researchers, secondly, the kind of the action research is collaborative, and thirdly, the action research er aimed at changing things.

The subject of this study was students of class VIIB. There were 32 students occupying in the class. The procedure for carrying out this action research consists of six steps. The steps are 
as follows: (1) Identifying the problems: the problems were identified first before planning the action. (2) Planning the action: general plan was made before implementing the action. (3) Implementing the action: the teacher implemented the action. (4) Observing/Monitoring: researcher observed and wrote all activities during the teaching learning process in a field note. (5) Reflecting the Result of the observation: Teacher and researcher made an evaluation on the observation result to find out the positive results and weaknesses during the action. (6) Revising the plan: Based on the weaknesses which were found in reflecting process, the teacher and researcher revise the action plan for the next cycle.

In this study, the data were collected through four techniques, namely interview, questionnaire, photographs, and test. Interview was used to know the strength and the weakness of the action. In order to know the students' speaking skill and their difficulties on speaking skill, the researcher conducted pre-test, while post-test was used to test the progress of the students' speaking competence.

\section{RESEARCH FINDING DISCUSSION}

AND

After implementing the action, the researcher found that the use of YouTube video in the teaching speaking had enhanced the students' speaking skill. The researcher planned four meetings in the first cycle and made a lesson plan for each meeting. In this cycle, he used the YouTube video for each meeting. In the first meeting, he focused on vocabulary related with describing animal. The researcher showed the material using YouTube video. Thereafter, the researcher explained about describing things; the definition, communicative function, and generic structure by using power point slideshow. The video is about the life of elephant in Africa. Then, he divided the students into eight groups. Each group consisted of four students. They was shown the video of students that describing animal as an example. It aimed to give them more models of describing animal so that they have more examples to explore their idea in speaking. Then, he showed a video about African Elephant, each group is tasked to make monologue about elephant. This intended to give students more idea and chance to practice their speaking and making their speaking more fluent.

In the second meeting, he focused on the vocabulary related to theme. In order to overcome the problem of students' limited vocabulary, the researcher asks students to write every word they can convey from the YouTube video, they also need to take a note about everything they see on the video. After the video end, the researcher asks random students to read words they get from the video and asks other students to discuss their finding with their group.

In the third meeting, he focused on the use of conjunction in making good descriptive monologue and improving students' grammar. To improve students' grammar, the researcher gives explanation about the structure of simple present tense and how to use conjunction in speaking. To drill students understanding about the grammar, the researcher give a set of sentence with blank space and order the students to fill the blank space with correct conjunction.

The fourth meeting was the first post-test. In the first post-test, the students had to describe animal in the picture. Meanwhile, in cycle 2, there were two meetings. The second meeting was the posttest 2 . In cycle 2 , the researcher focused on 
simple present tense, and the use of correct pronunciation in speaking.

Before the action, it was found that the students' speaking ability is still low. The problem faced by the students in speaking included the difficulty in expressing idea. It was shown by their limited vocabulary; low knowledge about pronunciation, they have difficulties in differentiating Indonesian sound system and English sound system. Even though, most of the students have got the idea of speaking as it has been taught in the beginning of the semester, the result showed that the students' attitude and motivation toward the English lesson especially speaking was still low.

During cycle 1 , in the classroom climate, the researcher found that there were some students who still did non-academic activities like chatting and drawing. Only few students who seemed not interested in participating in teaching learning process. In general, they really liked YouTube videos and working in groups. It built a competitive way to be the best and the fastest and cooperative way in finishing task. Nevertheless, several students still get difficulties in expressing their idea. They were not confidence enough and shy to show their skill and ability in front of other people. They needed to be motivated so that they could be involved more in the classroom activities. In negative side, the students' talk a lot often disturbed the classroom climate. In some occasion researcher took long time to manage the class until they were ready to start the teaching process. There are three students that difficult to control and strongly had the willingness to make noise in the class. They are often trying to disturb other students that paid attention to the lesson. In-group works, there were also some students did not give contribution to their group. They just pretended of being busy when the teacher monitored each group. They did not involve in groups' task. In the second cycle, the researcher should pay more attention on the individual work so that the students have the responsibility to finish their own work.

Besides finding some problems, the researcher found students' enhancement on speaking skill. It was proved by the enhancement of the mean score in port-test one compared to the pre-test result. The mean score of post-test 1 was 7.45 and the pre-test score was 5.64. It has showed enhancement on students' speaking skill. They had significant enhancement on almost each aspect of speaking except on pronunciation. The pre-test score on pronunciation was 2.67 and the post-test 1 score was 3.05. The researcher guessed that the lower score first post-test caused by students' careless on using correct pronunciation in speaking. To overcome this problem, the researcher gives more examples on correct pronunciation by showing YouTube video of a student that describing animal in order to give real example of correct pronunciation. After giving example the researcher drills students' pronunciation by telling them to pronounce words found in the video. To identify each student's understanding, he asked each student to pronounce the words individually and corrects mistakes done by the students immediately.

The researcher also found enhancements in students' attitudes when given chance to speaking, before the implementation students often reject to perform in front of the class. In the early meeting, the students were still ashamed to get involved in the activities, but in the next meeting, most of them began to participate actively by giving their opinion and sharing their idea. They also tried to be active in 
answering the researcher's question and responding the researcher's instructions. They were interested and motivated to join and get involved in the speaking class.

After analyzing the observation result and the test result in the second cycle, the researcher did reflection in order to evaluate the teaching and learning process. He found the students' made positive progress in speaking ability. The observation result showed that there were some enhancements achieved after the action was implemented.

The enhancements involved the students' speaking skill and the students' attitudes toward speaking itself. The students' speaking skill got significant enhancement from the first cycle. The mean score of post-test 2 was 79.5. It was much better than the mean score of post-test 1 which was 7.45. In the second cycle, the students showed great enthusiasm toward the lesson. It was proved by their participation in giving opinion and asking questions when they found any difficulties. In addition, they gave their full attention to the researcher's explanation and could respond to the instructions from the researcher. They have courage to express their opinions and ideas. They were not nervous anymore to present their work in front of their friends. Besides, the students' mastery of vocabularies was better. Their speaking was better both in quality and in quantity. Therefore, it can be concluded that the application of YouTube video can improve the students' skill.

Moreover, the use of YouTube video as a teaching media in speaking class gave new atmosphere for the students. The students showed positive attitudes towards speaking lesson. The students become more active and enthusiastic both in responding to the researcher and in finishing the task given. The students' attitude toward speaking got better. They were not reluctant anymore to speak. It was not hard to ask them to present their monologue in front of the class. They were interested and motivated to join and to get involved in the teaching learning process. They were also more responsible in finishing their task both individual and group task. There were great enhancements in the students' attitude toward speaking lesson and students' speaking skill.

\section{CONCLUSION AND SUGGESTION}

Based on the findings of the research, the researcher found important aspects to conclude. The first conclusion is the application of YouTube video in speaking class can improve students' speaking skill on some aspects of speaking as mentioned in the research findings.

The second conclusion is the application of YouTube video in speaking class able to improve the classroom climate during the teaching-learning process. Based on the research findings, the YouTube video created conducive atmosphere and made the students were actively involved in finishing their works both in individual and group works. The students showed great enthusiasm toward the lesson, paid more attention to the teacher, and got more selfconfidence in performing their speaking in front of people.

Based on the research findings, the writer would like to give suggestions that the teachers should use attractive and interesting media with the appropriate teaching method. They could use YouTube video as an interactive and attractive media. Before implementing YouTube video, the teacher should consider the level of students' proficiency as well as language 
function that have been mastered by the students.

Meanwhile, for other researcher it is expected that the result of this research can be used as a foothold in conducting classroom action research by using YouTube video to improve other skills like writing, reading, and listening. The other researcher can use this thesis as reference for their own research.

\section{BIBLIOGRAPHY}

Brophy, J.E. (1988). "Educating Teachers About Managing Classrooms and Students." Teaching and Teacher Education 4. 1-18.

Brown, G., \& Yule, G. (1983). Teaching the Spoken Language. Cambridge: Cambridge University Press.

Burns, Anne. (1999). Collaborative Action Research for English Language Teachers. Cambridge: Cambridge University Press.

Canning-Wilson, Christine. (2000). "Practical Aspects of Using Videos in the Foreign Language Classroom". The Internet TESL Journal. 6 (11). Retrieved December 2010 from http://iteslj.org/Articles/CanningVideo.html

Cooper, Richard. (1991). Video. Oxford: Oxford University Press.

Nunan, David. (1992). Research Method in Language Learning.Cambridge: Cambridge University Press.

Hopkins, Jim. (2006). "Surprise! There's a Third YouTube Co-Founder". USA Today, October 2006.

Mills, Geofrey E. (2000). Action Research: A Guide for the Teacher Researcher. New Jersey: Prentice Hall Inc.
Smaldino, et al. (2005). Instructional Technology and Media for Learning (Eight Edition). New Jersey: Pearson Education.

Suparno. (2010). Optimizing the Use of "YouTube Videos" to Improve Students' Speaking Ability (A Classroom Action Research in the Ninth Grade Students of SMPN 1 Kerjo in the Academic year of 200/2010). Unpublished Master Degree Thesis of English Education Department. Sebelas Maret University. Surakarta.

Ur, Penny. (1996). A Course on Language Teaching. Cambridge: Cambridge University Press.

Wallace, Michael J. (1998). Action Research for Language Teachers. Cambridge: University Press Cambridge. 